\section{Secondary Macro- and Microelements in Sphagnum Peat-based Substrates Amended with Parboiled Fresh Rice Hulls or Perlite}

\author{
Michael R. Evans ${ }^{1,3}$ and Mary M. Gachukia ${ }^{2}$
}

AdDITIONAL INDEX wORDs. Root media, substrate chemistry, PBH, manganese

SUMMARY. Substrates were formulated by blending parboiled fresh rice (Oryza sativa) hulls $(\mathrm{PBH})$ or perlite with sphagnum peat (peat) to produce root substrates (substrates) that contained $20 \%, 30 \%, 40 \%, 50 \%$, or $60 \%$ (by volume) $\mathrm{PBH}$ or perlite with the remainder being peat. After 0,4 , or 8 weeks in a greenhouse environment, samples were taken and calcium $(\mathrm{Ca})$, magnesium $(\mathrm{Mg})$, sulfur $(\mathrm{S})$, iron $(\mathrm{Fe})$, manganese $(\mathrm{Mn})$, copper $(\mathrm{Cu})$, zinc $(\mathrm{Zn})$, and boron $(\mathrm{B})$ were determined. At all sampling times, substrates containing $\mathrm{PBH}$ had higher $\mathrm{Ca}$ concentrations than perlite-containing substrates. At all sampling times, Ca concentration decreased as the amount of perlite or PBH was increased, but the Ca concentration decreased at a higher rate in perlite-containing substrates than in $\mathrm{PBH}$-containing substrates. After 0 weeks, perlite-containing substrates had higher $\mathrm{Mg}$ concentrations than equivalent $\mathrm{PBH}$-containing substrates, but the opposite was true after 4 weeks. After 8 weeks, perlite- and PBH-containing substrates had similar concentrations of $\mathrm{Mg}$. At all times, $\mathrm{Mg}$ concentration decreased as the amount of perlite or $\mathrm{PBH}$ was increased. Perlite substrates had higher concentrations of $\mathrm{Fe}$ than equivalent $\mathrm{PBH}$ substrates, and as the amount of perlite or $\mathrm{PBH}$ was increased, the amount of $\mathrm{Fe}$ decreased. $\mathrm{PBH}$-containing substrates had higher concentrations of $\mathrm{Mn}$ than equivalent perlite-containing substrates, and as the amount of $\mathrm{PBH}$ was increased, the amount of $\mathrm{Mn}$ increased. Cu concentrations were significantly affected by sampling time, but at all sampling times, $\mathrm{PBH}$-containing substrates had similar or higher $\mathrm{Cu}$ concentrations than equivalent perlite-containing substrates. Perlite substrates had higher concentrations of $\mathrm{Zn}$ than equivalent $\mathrm{PBH}$ substrates, and as the amount of perlite was increased, the amount of $\mathrm{Zn}$ increased. S and B were not significantly affected by substrate component or time. Secondary macro- and microelement concentrations of all substrates were within recommended levels for greenhouse crops except for Mn. Mn concentrations were within recommended ranges at up to $50 \% \mathrm{PBH}$. In most cases, $\mathrm{PBH}$ would be used at levels lower than $\mathbf{5 0 \%}$, but in cases where more than $50 \% \mathrm{PBH}$ were used in the substrate, proper $\mathrm{pH}$ management may be important to prevent excessive $M n$ availability.

$\mathrm{R}$ oot substrates (substrates) are commonly used in the production of containerized greenhouse and nursery crops (Bunt 1988; Nelson, 2003). Substrates are formulated from various inorganic and organic components to provide suitable physical and chemical properties as required by the specific crop and growing conditions (Bunt, 1988). One important physical property of substrates is air-filled pore space (Bunt, 1988). Air-filled pores allow for drainage and gas exchange between the root environment and the outside atmosphere. Various materials have been used to provide for air-filled pore space in substrates,

Department of Horticulture, University of Arkansas, 315 Plant Science Bldg., Fayetteville, AR 72701

${ }^{1}$ Associate Professor.

${ }^{2}$ Graduate Student.

${ }^{3}$ Corresponding author. E-mail: mrevans@uark.edu. with one of the most common being perlite (Bunt, 1988).

Perlite is an inorganic expanded aluminosilicate of volcanic origin (Nelson, 2003), and it is produced by mining the ore, grinding the crude ore to the desired particle size, and heating it to temperatures of up to $982{ }^{\circ} \mathrm{C}$. Heating causes the ore to expand from four to 20 times its original volume, resulting in a lightweight white porous particle (Hanan, 1998). Because of the costs associated with mining, transportation, and heating, perlite has been a relatively expensive substrate component. In addition to its cost, in its dry state, perlite produces a siliceous dust that is an eye and lung irritant. Substrate components that are lower in cost, do not have the dust issues associated with perlite, and could provide for airfilled pore space in the substrate would be beneficial to the nursery and greenhouse crop industries.

Many potential alternative components to perlite (i.e., shredded rubber and ground bovine bone) had undesirable chemical properties. For example, ground bovine bone had too high of a $\mathrm{pH}$ as well as a high ammonium $\left(\mathrm{NH}_{4}{ }^{+}\right)$concentration (Evans, 2004). Shredded rubber tires had high concentrations of $\mathrm{Zn}$ that were phytotoxic to many commonly grown greenhouse crops (Evans and Harkess, 1997). Other materials evaluated as potential alternatives to perlite were too expensive or had unacceptably high bulk densities (i.e., calcined clay aggregates and gravel) that resulted in unacceptably high shipping costs for most crops and have thus been limited in their use.

Rice hulls are a milling coproduct of the rice industry. Rice is produced over large areas of Asia. In Europe, most rice is produced in Italy's Po River Valley, and in the United States, it is produced primarily in Arkansas, Texas, Louisiana, Mississippi, and California. With the rice hull comprising $\approx 20 \%$ of the harvested grain by weight (Kamath and Proctor, 1998), rice hulls are an abundant and readily available material throughout much of the world.

Parboiled rice hulls $(\mathrm{PBH})$ are a type of fresh rice hull obtained as a result of a steaming process and are therefore sterile and free of viable weed seeds when initially produced. Evans and Gachukia (2004) demonstrated that PBH could be successfully used as an alternative to perlite in the root substrate for the production of several ornamental species. Evans and Gachukia (2007) also reported

\begin{tabular}{llll}
\hline $\begin{array}{l}\text { Units } \\
\text { To convert U.S. to SI, } \\
\text { multiply by }\end{array}$ & U.S. unit & SI unit & $\begin{array}{l}\text { To convert SI to U.S., } \\
\text { multiply by }\end{array}$ \\
\hline 29.5735 & $\mathrm{fl} \mathrm{oz}$ & $\mathrm{mL}$ & 0.0338 \\
2.54 & inch $(\mathrm{es})$ & $\mathrm{cm}$ & 0.3937 \\
1 & $\mathrm{ppm}$ & $\mathrm{mg} \cdot \mathrm{kg}^{-1}$ & 1 \\
1 & $\mathrm{ppm}$ & $\mathrm{mg} \cdot \mathrm{L}^{-1}$ & 1 \\
$\left({ }^{\circ} \mathrm{F}-32\right) \div 1.8$ & ${ }^{\circ} \mathrm{F}$ & ${ }^{\circ} \mathrm{C}$ & $\left(1.8 \times{ }^{\circ} \mathrm{C}\right)+32$
\end{tabular}


how PBH affected physical properties of sphagnum peat-based substrates compared with perlite, and they reported that the bulk density of perlite and $\mathrm{PBH}$ were similar. However, the effects that $\mathrm{PBH}$ has on the chemical properties of sphagnum peat-based substrates compared with perlite have not been reported.

The objectives of this study were to determine the effect of increasing concentrations of $\mathrm{PBH}$ and perlite on the secondary macroelement and microelement concentrations of a sphagnum peat-based substrate, to determine if these chemical properties were affected differently by increasing amounts of $\mathrm{PBH}$ and perlite, and to determine if these chemical properties were within acceptable ranges for use in greenhouse crop root substrates.

\section{Materials and methods}

$\mathrm{PBH}$ were obtained from Riceland Foods (Stuttgart, AR). Perlite and sphagnum peat (peat) were obtained from Sun Gro Horticulture (Bellevue, WA). Perlite and PBH had an initial $\mathrm{pH}$ of 7.5 and 6.5 , respectively. Peat had an initial $\mathrm{pH}$ of 3.5. However, calcitic limestone was added to the peat $7 \mathrm{~d}$ before formulation of the substrates to adjust the $\mathrm{pH}$ to $\approx 5.0$.

Ten substrates were formulated by blending $\mathrm{PBH}$ or perlite in a rotary mixer for $1 \mathrm{~min}$ at $50 \mathrm{rpm}$ to produce root substrates that contained $20 \%$, $30 \%, 40 \%, 50 \%$, or $60 \%$ (by volume) $\mathrm{PBH}$ or perlite with the remainder being peat. The substrates were moistened to $60 \%$ (by weight) during mixing with deionized water. Substrates were then placed into $10-\mathrm{cm}$ - diameter $(600 \mathrm{~mL})$ plastic containers without compaction. Containers were transferred to a glass-glazed greenhouse. Air temperatures were maintained between $20^{\circ} \mathrm{C}$ and $25^{\circ} \mathrm{C}$ under ambient light levels (350-525 $\mu \mathrm{mol} \cdot \mathrm{s}^{-1} \cdot \mathrm{m}^{-2}$ at $1200 \mathrm{HR}$ ) and naturally occurring photoperiods from April through September in Fayetteville, AR. The substrates in each container were maintained moist, but without leaching, by applying 60 $\mathrm{mL}$ of deionized by hand on alternating days to the surface of each substrate.

Substrate samples were taken after 0 (initial mixing), 4 , and 8 weeks in the greenhouse environment. These times were selected to determine initial parameters, parameters in the middle of a typical annual bedding plant greenhouse crop cycle, and parameters near the end of such a greenhouse crop cycle.

Substrate nutrient status was determined using the saturated media extract method as outlined by the North Central Regional Committee for Soil and Plant Analysis (Warncke, 1988). The concentrations of $\mathrm{Ca}$, $\mathrm{Mg}, \mathrm{S}, \mathrm{Fe}, \mathrm{Mn}$, molybdenum (Mo), $\mathrm{Cu}, \mathrm{Zn}$, and $\mathrm{B}$ were determined using the filtered extract for simultaneous inductively coupled plasma emission spectrometry (Jones, 1977; Munter and Grande, 1981).

The experimental design was a completely randomized design with nine replications per substrate and sampling time. Each container served as a replication. An analysis of variance was conducted to determine if substrate component, component percentage, or time in the greenhouse environment affected the chemical properties and whether significant interactions occurred among these variables. For each sampling time, substrate chemical properties were regressed against the percentage of $\mathrm{PBH}$ or perlite to determine how the amount of each affected each chemical property tested.

\section{Results and discussion}

Substrate Ca was significantly affected by substrate component, component percentage, and sampling time (Table 1). Only the interaction between component and percentage of component was significant. At all sampling times, $\mathrm{PBH}$-containing substrates had higher $\mathrm{Ca}$ concentrations than equivalent perlite-containing substrates (Fig. 1, A-C). Furthermore, at all sampling times, the $\mathrm{Ca}$ concentrations of the substrates decreased as the amount of $\mathrm{PBH}$ or perlite increased. However, the rate of decrease in Ca concentrations was higher for perlite-containing substrates than for $\mathrm{PBH}$-containing substrates.

The major source of $\mathrm{Ca}$ in the substrates was the peat that had been amended with calcitic limestone, therefore increasing the amount of perlite or $\mathrm{PBH}$ reduced the amount of peat and thus the concentration of calcium in the substrate. Cadell (1988) reported that rice hulls contained $950 \mathrm{mg} \cdot \mathrm{kg}^{-1} \mathrm{Ca}$, whereas perlite contained only trace amounts of calcium (Perlite Institute, 2005). Therefore, the differences in the $\mathrm{Ca}$ concentrations between equivalent perlite- and $\mathrm{PBH}$-containing substrates could have been a function of the Ca concentration of the rice hulls.

Table 1. Main effect and interactions for secondary macro- and microelement concentration of sphagnum peat-based substrates amended with parboiled fresh rice hulls or perlite.

\begin{tabular}{|c|c|c|c|c|c|c|c|}
\hline $\begin{array}{l}\text { Mineral } \\
\text { element }^{\mathrm{z}}\end{array}$ & Component $^{\mathrm{y}}$ & Component $\%^{x}$ & Time $^{\mathrm{w}}$ & $\begin{array}{l}\text { Component } \times \\
\text { Component } \%\end{array}$ & $\begin{array}{c}\text { Component } \times \\
\text { Time }\end{array}$ & $\begin{array}{c}\text { Component } \% \times \\
\text { Time }\end{array}$ & $\begin{array}{l}\text { Component } \times \\
\text { Component } \% \times \\
\text { Time }\end{array}$ \\
\hline $\mathrm{Ca}$ & $\star * \star$ & $* * *$ & * & * * & NS & NS & NS \\
\hline $\mathrm{Mg}$ & $* * *$ & *** & $* * *$ & *** & ** & NS & * \\
\hline S & NS & NS & $* *$ & NS & NS & NS & NS \\
\hline $\mathrm{Fe}$ & $* * *$ & $* * *$ & $* * *$ & $* * *$ & $* * *$ & ** & NS \\
\hline $\mathrm{Mn}$ & $\star * *$ & *** & $\star * *$ & ** * & $\star * *$ & $* * *$ & $* * *$ \\
\hline $\mathrm{Cu}$ & * & ** & $* * *$ & $* * *$ & * & $* * *$ & $* * *$ \\
\hline $\mathrm{Zn}$ & $\star * *$ & $* * *$ & $\star * *$ & $* * *$ & $* * *$ & $* * *$ & $\star * *$ \\
\hline
\end{tabular}

${ }^{\mathrm{z}}$ Calcium $(\mathrm{Ca})$, magnesium $(\mathrm{Mg})$, sulfur $(\mathrm{S})$, iron $(\mathrm{Fe})$, manganese $(\mathrm{Mn})$, copper $(\mathrm{Cu})$, and zinc $(\mathrm{Zn})$.

${ }^{y}$ Components refers to perlite or parboiled fresh rice hulls.

$\mathrm{x} \%$ Component $=$ percentage of perlite or parboiled fresh rice hulls in the peat-based substrates $(20 \%, 30 \%, 40 \% 50 \%$, or $60 \%$ by volume $)$

wTime = substrate sampling time $(0,4$, and 8 weeks in a greenhouse environment $)$

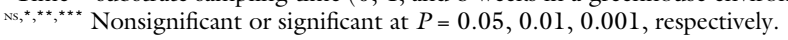


The Ca concentrations for all of the substrates were within acceptable ranges for unused substrates (Bunt, 1988; Nelson, 2003; Peterson et al., 1989).

Substrate $\mathrm{Mg}$ was significantly affected by substrate component, component percentage, and sampling time (Table 1). There were significant interactions between substrate component and time, as well as between substrate component, component percentage, and time. After 0 weeks, perlite-containing substrates had a higher $\mathrm{Mg}$ concentration than equivalent PBH-containing substrates (Fig. 2A). After 4 weeks, PBH-containing substrates had a higher $\mathrm{Mg}$ concentration than equivalent perlitecontaining substrates (Fig. 2B). After 0 and 4 weeks, the $\mathrm{Mg}$ concentration decreased as perlite or $\mathrm{PBH}$ was increased. After 8 weeks, equivalent perlite- and PBH-containing substrates had similar $\mathrm{Mg}$ concentrations, and as perlite or $\mathrm{PBH}$ was increased, the $\mathrm{Mg}$ concentration decreased (Fig. 2C).

The primary Mg source appeared to have been the peat because increasing $\mathrm{PBH}$ or perlite reduced the $\mathrm{Mg}$ concentrations. Perlite and $\mathrm{PBH}$ contained $\mathrm{Mg}$ (Cadell,1988; Perlite Institute, 2005), but the difference in Mg levels between week 0 and week 4 may have been due to the rate at which $\mathrm{Mg}$ in the perlite or $\mathrm{PBH}$ was released into the substrate. For all substrates and sampling times, $\mathrm{Mg}$
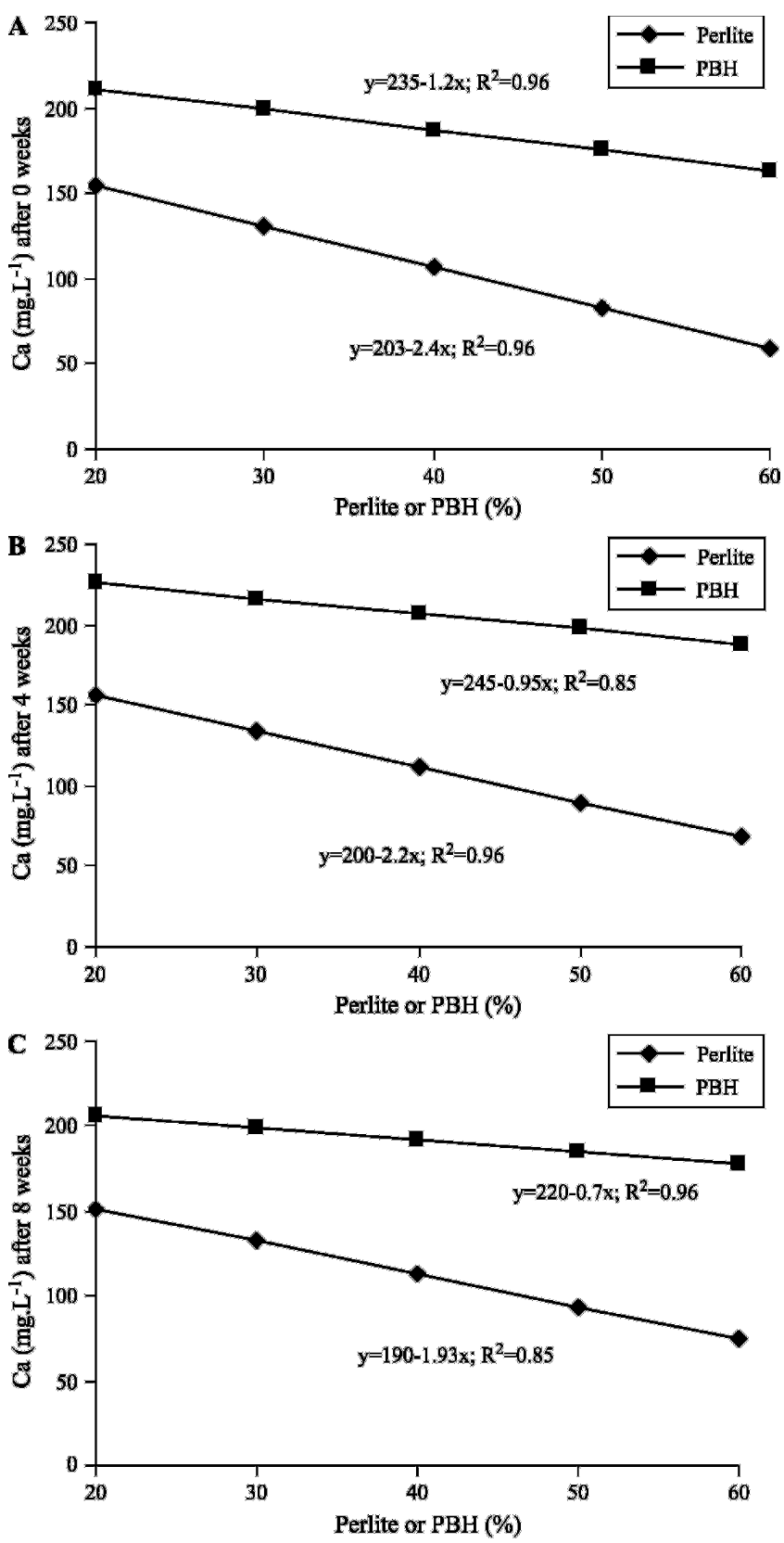

Fig. 1. Substrate calcium (Ca) concentration as affected by perlite and parboiled fresh rice hull $(\mathrm{PBH})$ concentration after 0,4 , and 8 weeks $\left(1 \mathrm{mg} \cdot \mathrm{L}^{-1}=1 \mathrm{ppm}\right)$.
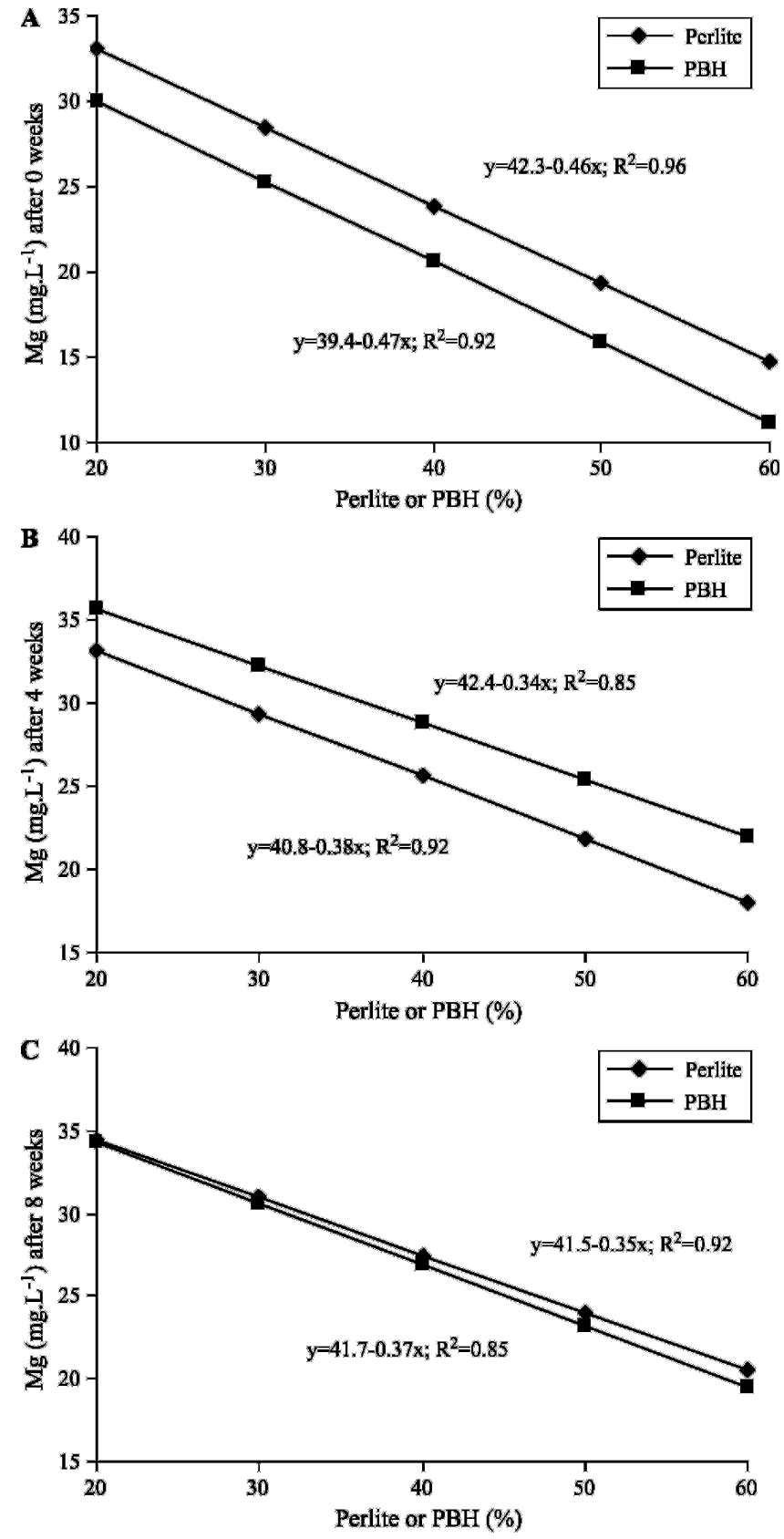

Fig. 2. Substrate magnesium $(\mathrm{Mg})$ concentration as affected by perlite and parboiled fresh rice hull $(\mathrm{PBH})$ concentration after 0,4 , and 8 weeks $\left(1 \mathrm{mg} \cdot \mathrm{L}^{-1}=1 \mathrm{ppm}\right)$. 
levels were within recommended ranges for greenhouse crops (Bunt, 1988; Nelson, 2003; Peterson et al., 1989).

Substrate $S$ was not significantly affected by substrate component or percentage of substrate component. Only time significantly affected substrate $S$ concentration (Table 1 ). Root substrates had $S$ concentrations of 35,30 , and $28 \mathrm{mg} \cdot \mathrm{L}^{-1}$ at weeks 0,4 , and 8 , respectively (data not shown). All substrate $S$ concentrations were within the maximum recommended ranges for greenhouse crops (Bunt, 1988; Nelson, 2003; Peterson et al., 1989).

Substrate $\mathrm{Fe}$ was significantly affected by substrate component, component percentage, and sampling time. All two-way interactions among the main effects were significant (Table 1). For all sampling times, substrates containing $20 \%$ perlite or $20 \% \mathrm{PBH}$ had similar substrate $\mathrm{Fe}$ concentrations (Fig. 3, A-C). As the amount of perlite or $\mathrm{PBH}$ increased, the Fe concentration decreased. However, the Fe concentration decreased at a higher rate in the $\mathrm{PBH}$-containing substrates so that substrates containing more than $20 \%$ perlite had a higher Fe concentration than equivalent $\mathrm{PBH}$-containing substrates.

Perlite is of a mineral origin and contained higher concentrations of Fe than PBH (Cadell, 1988; Perlite Institute, 2005) and thus perlitecontaining substrates had higher Fe concentrations than equivalent
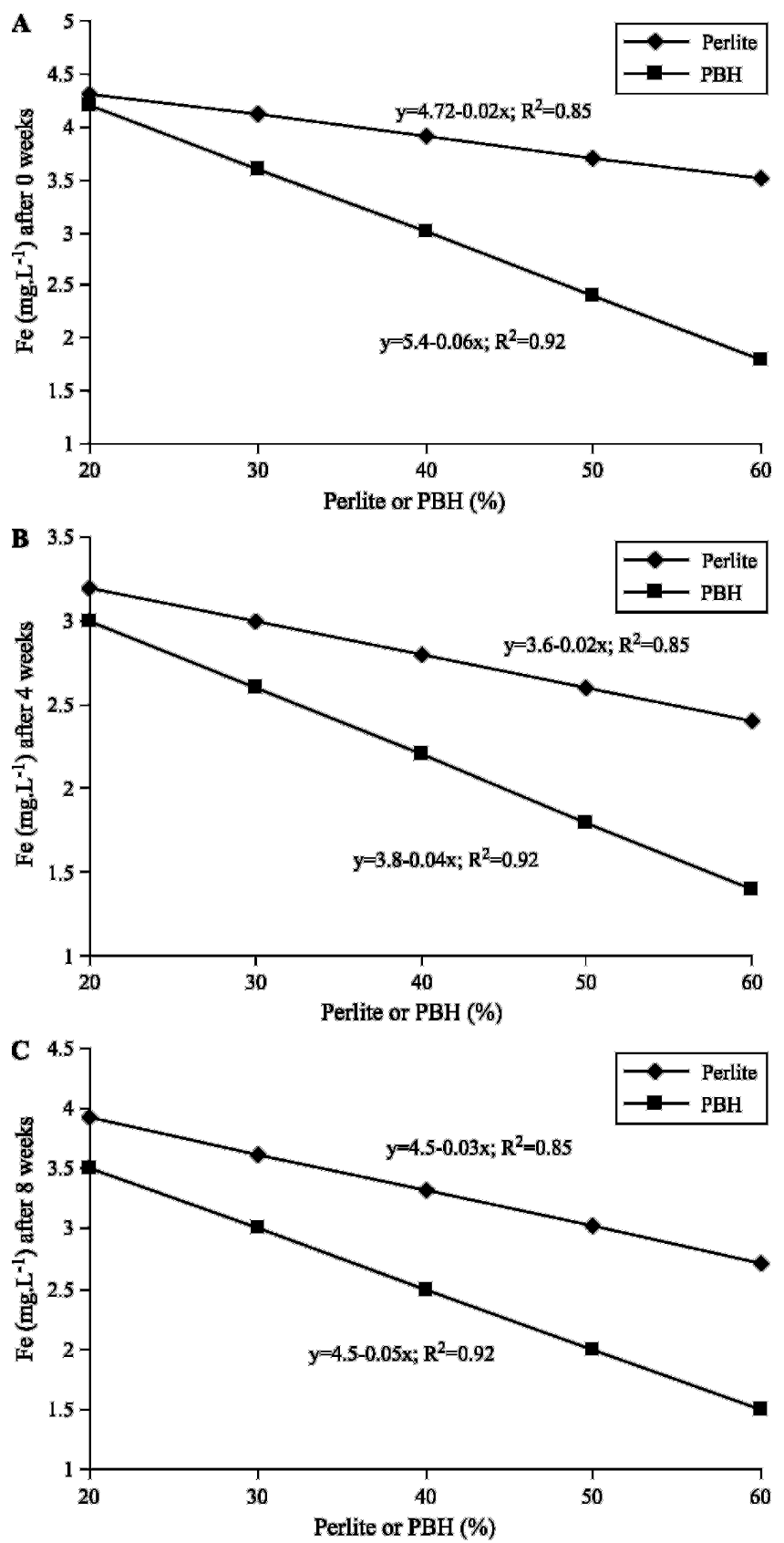

Fig. 3. Substrate iron $(\mathrm{Fe})$ concentration as affected by perlite and parboiled fresh rice hull $(\mathrm{PBH})$ concentration after 0,4 , and 8 weeks.
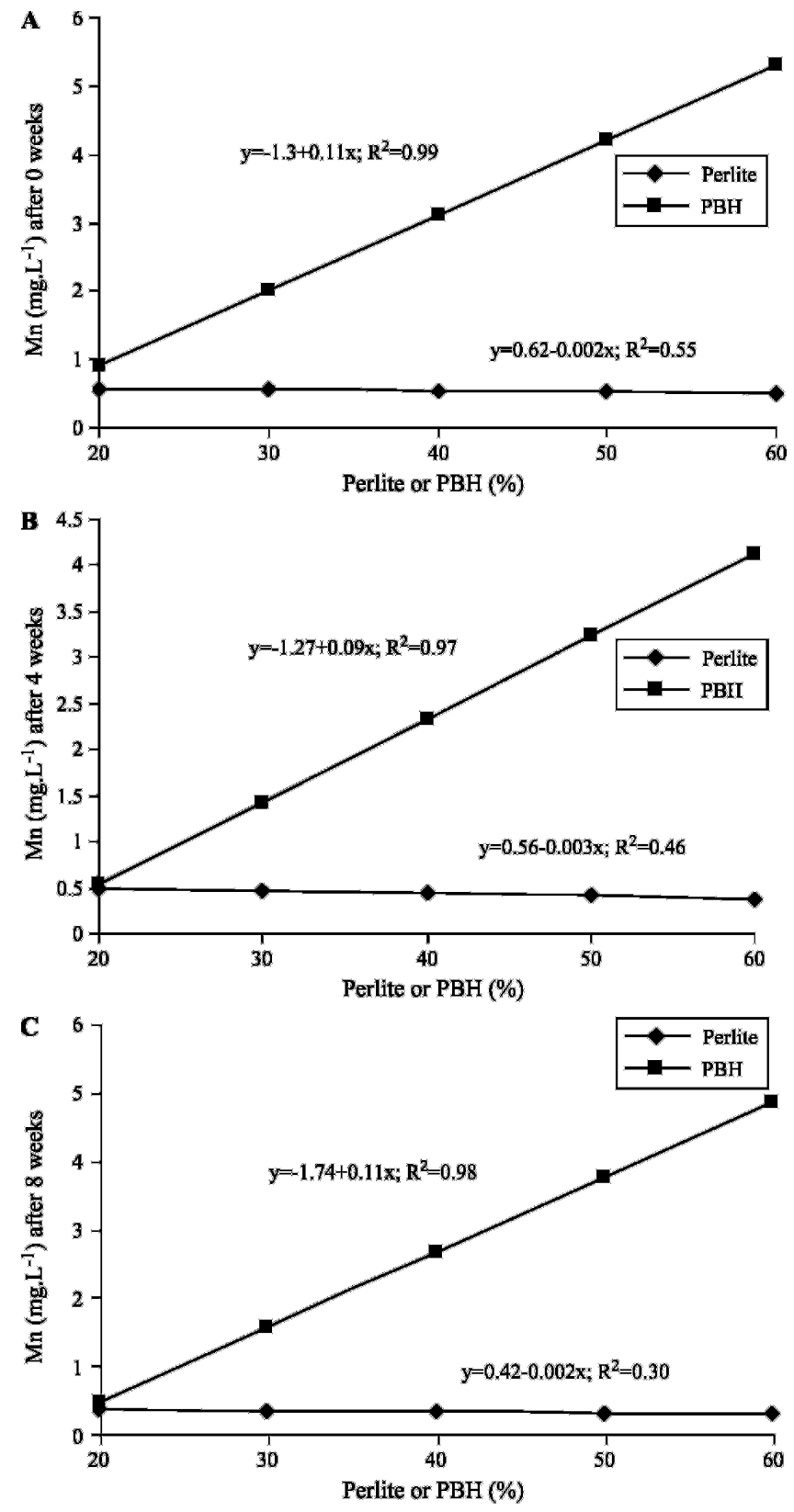

Fig. 4. Substrate manganese (Mn) concentration as affected by perlite and parboiled fresh rice hull $(\mathrm{PBH})$ concentration after 0,4 , and 8 weeks $\left(1 \mathrm{mg} \cdot \mathrm{L}^{-1}=1 \mathrm{ppm}\right)$. 
PBH-containing substrates. The Fe concentrations of all perlite- and $\mathrm{PBH}$-containing substrates were within the maximum recommended acceptable ranges (Bunt, 1988; Nelson, 2003; Peterson et al., 1989).

Substrate Mn was significantly affected by substrate component, component percentage, and sampling time. All potential interactions were significant (Table 1). For all sampling times, substrates containing $20 \%$ perlite or $20 \% \mathrm{PBH}$ had similar manganese concentrations (Fig. 4, A-C).
However, as PBH increased, the Mn concentration increased, while as the amount of perlite increased, the Mn concentration decreased.

Rice hulls were reported to contain significant concentrations of $\mathrm{Mn}$ (Cadell, 1988). This contributed to PBH-containing substrates having higher Mn concentrations than perlite-containing substrates and to the increasing $\mathrm{Mn}$ concentrations with increasing amounts of PBH. Steaming of rice hulls for use in substrates was reported to result in Mn concen- trations that were above recommended concentrations and potentially phytotoxic (Einert, 1972). However, after 0 weeks, substrates containing up to $40 \% \mathrm{PBH}$ had Mn concentrations within recommended levels. After 4 and 8 weeks, substrates containing up to $50 \% \mathrm{PBH}$ had Mn concentrations within acceptable levels (Bunt, 1988; Nelson, 2003; Peterson et al., 1989).

Substrate $\mathrm{Cu}$ concentration was significantly affected by substrate component, component percentage,
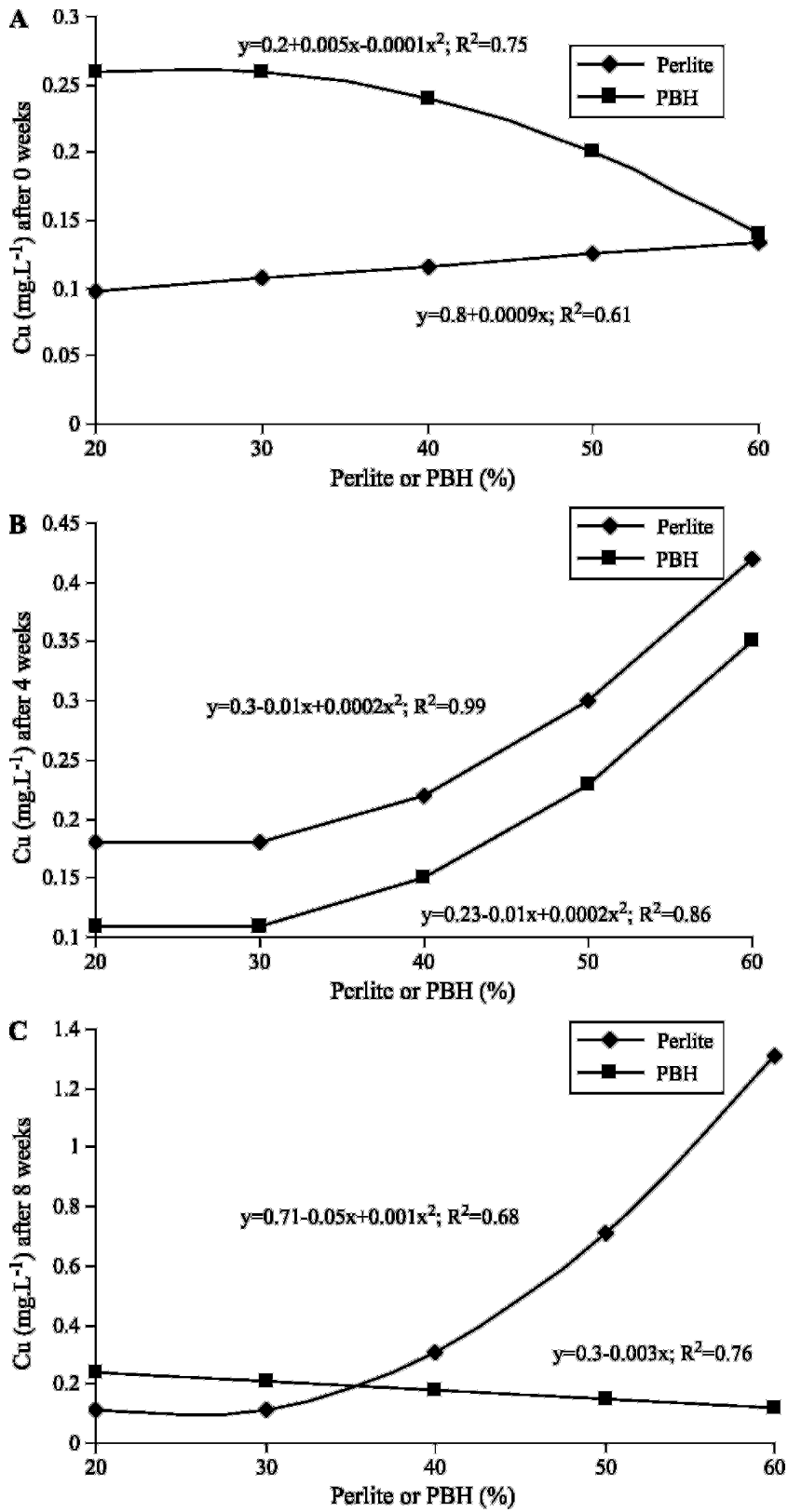

Fig. 5. Substrate copper $(\mathrm{Cu})$ concentration as affected by perlite and parboiled fresh rice hull $(\mathrm{PBH})$ concentration after 0,4 , and 8 weeks $\left(1 \mathrm{mg} \cdot \mathrm{L}^{-1}=1 \mathrm{ppm}\right)$.
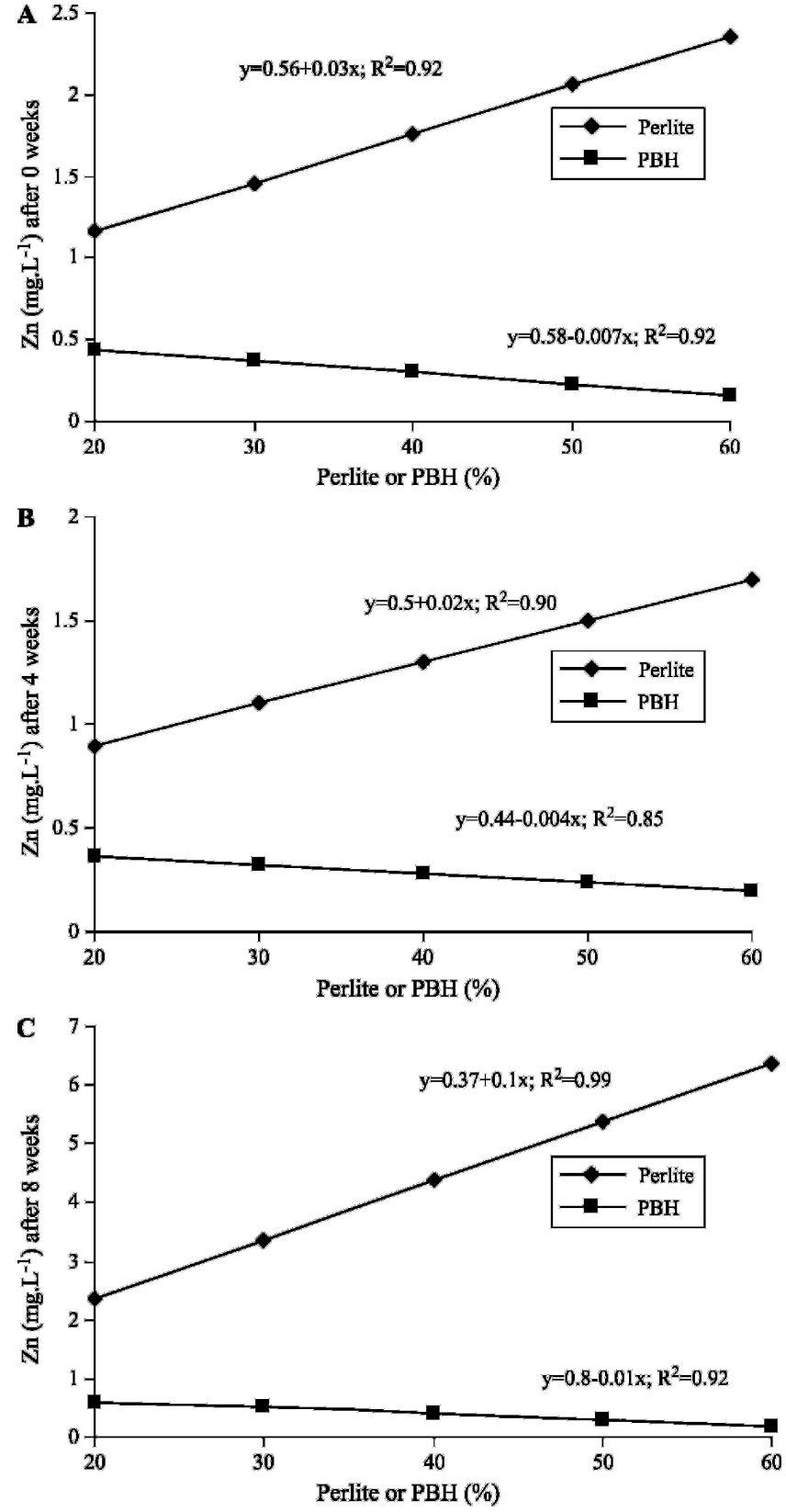

Fig. 6. Substrate zinc $(\mathrm{Zn})$ concentration as affected by perlite and parboiled fresh rice hull $(\mathrm{PBH})$ concentration after 0,4 , and 8 weeks $\left(1 \mathrm{mg} \cdot \mathrm{L}^{-1}=1 \mathrm{ppm}\right)$. 
and sampling time. All interactions among the main effects were significant (Table 1). After 0 weeks, $\mathrm{Cu}$ concentration was higher in the substrate containing $20 \% \mathrm{PBH}$ than in the $20 \%$ perlite substrate (Fig. 5A). As the amount of $\mathrm{PBH}$ was increased, the $\mathrm{Cu}$ concentration decreased. As the amount of perlite increased, the $\mathrm{Cu}$ concentration increased until the $\mathrm{Cu}$ concentration was similar for substrates containing $60 \%$ perlite or $\mathrm{PBH}$. After 4 weeks, $\mathrm{Cu}$ concentration was higher in all perlite-containing substrates compared with equivalent $\mathrm{PBH}$-containing substrates (Fig. 5B). As perlite or $\mathrm{PBH}$ was increased, the $\mathrm{Cu}$ concentration increased. After 8 weeks, substrates containing 20\% or $30 \% \mathrm{PBH}$ had a higher $\mathrm{Cu}$ concentration than equivalent perlitecontaining substrates (Fig. 5C). As the amount of $\mathrm{PBH}$ increased, the $\mathrm{Cu}$ concentration decreased so that substrates containing $40 \%$ or more perlite had higher $\mathrm{Cu}$ concentrations than equivalent $\mathrm{PBH}$-containing substrates.

The most dramatic difference in $\mathrm{Cu}$ concentrations was the factor of time. These differences are likely due to the amount of $\mathrm{Cu}$ supplied by perlite and $\mathrm{PBH}$ as well as the rate of release of $\mathrm{Cu}$ into the substrate. Some $\mathrm{Cu}$ was released from perlite immediately, whereas little $\mathrm{Cu}$ was released from the PBH immediately. However, after 4 weeks, $\mathrm{Cu}$ was released from perlite and $\mathrm{PBH}$. After 8 weeks, perlite no longer released $\mathrm{Cu}$ into the substrate, while $\mathrm{PBH}$ continued to release $\mathrm{Cu}$. Therefore, the rate at which $\mathrm{Cu}$ was released into the substrate was significantly different between perlite and $\mathrm{PBH}$. The difference in $\mathrm{Cu}$ concentrations among the substrates was not high enough to be of practical significance, and the $\mathrm{Cu}$ concentration of all substrates was within recommended levels for greenhouse crops (Bunt, 1988; Nelson, 2003; Peterson et al., 1989).

Substrate $\mathrm{Zn}$ was significantly affected by substrate components, component percentage, and sampling time. All interactions among the main effects were significant (Table 1). At all sampling times, perlite-containing substrates had higher $\mathrm{Zn}$ concentra- tions than equivalent $\mathrm{PBH}$-containing substrates (Fig. 6, A-C). As the amount of perlite was increased, the Zn substrate concentration increased, while as the amount of $\mathrm{PBH}$ was increased, the $\mathrm{Zn}$ concentration decreased.

As in the case of $\mathrm{Fe}$, perlite contained significant levels if $\mathrm{Zn}$ and this was released into the substrate. The difference in $\mathrm{Zn}$ concentrations among the substrates was not high enough to be of practical significance, and the $\mathrm{Zn}$ concentration of all substrates was within maximum recommended levels for greenhouse crops (Bunt, 1988; Nelson, 2003; Peterson et al., 1989).

Substrate B and Mo were not significantly affected by substrate component, component percentage, or time (Table 1). Perlite- and $\mathrm{PBH}-$ containing substrates had B concentrations of $0.1 \mathrm{mg} \cdot \mathrm{L}^{-1}$ and $\mathrm{Mo}$ concentrations of $0.0 \mathrm{l} \mathrm{mg} \cdot \mathrm{L}^{-1}$, respectively, for all component percentages and sampling times (data not shown). The concentrations of $\mathrm{B}$ and $\mathrm{Mo}$ were within the recommended range for greenhouse crops (Bunt, 1988; Nelson, 2003; Peterson et al., 1989).

\section{Conclusion}

With the exception of $\mathrm{Mn}$, all secondary macro- and microelement concentrations of $\mathrm{PBH}$-containing substrates were similar to their respective perlite controls or were within the maximum recommended ranges for greenhouse crops. Mn concentrations were higher in $\mathrm{PBH}$-containing substrates than perlite substrates and were above the recommended concentrations when more than 50\% $\mathrm{PBH}$ was included in the substrate. Therefore, in situations where crops sensitive to $\mathrm{Mn}$ toxicity are to be grown, maintaining optimal $\mathrm{pH}$ and limiting $\mathrm{PBH}$ content to $50 \%$ or lower may be necessary to prevent the occurrence of excessive available $\mathrm{Mn}$ in the substrate.

\section{Literature cited}

Bunt, A.C. 1988. Media and mixes for container grown plants. Unwin Hyman, London.
Cadell, M.L. 1988. Rice hull composting in Australia. Biocycle 29:49.

Einert, A.E. 1972. Performance of rice hulls as a growing media for pot lilies under three forcing systems. HortScience 7:60-61.

Evans, M.R. 2004. Ground bovine bone as a perlite alternative in horticultural substrates. HortTechnology 14:171-175.

Evans, M.R. and M. Gachukia. 2004. Fresh parboiled rice hulls serve as an alternative to perlite in greenhouse crop substrates. HortScience 39:232-235.

Evans, M.R. and M.M. Gachukia. 2007. Physical properties of sphagnum peatbased root substrates amended with perlite or parboiled fresh rice hulls. HortTechnology 17:312-315.

Evans, M.R. and R.L. Harkess. 1997. Growth of Pelargonium $\times$ hortorum and Eurphorbia pulcherrima in rubbercontaining substrates. HortScience 32: 874-877.

Hanan, J.J. 1998. Greenhouse-advanced technology for protected horticulture. CRC Press, Boca Raton, FL.

Jones J.B., Jr. 1977. Elemental analysis of soil extracts and plant tissue ash by plasma emission spectroscopy. Commun. Soil Sci. Plant Anal. 8:345-365.

Kamath, S.R. and A. Proctor. 1998. Silica gel from rice hull ash: Preparation and characterization. Cereal Chem. 75(4): 484-487.

Munter, R.C. and R.A. Grande. 1981. Plant tissue and soil extract analysis by ICP-atomic emission spectrometry, $\mathrm{p}$. 653-672. In: R.M. Barnes (ed.). Developments in atomic plasma spectrochemical analysis.. Heyden and Sons, London.

Nelson, P.V. 2003. Greenhouse operation and management. 5th ed. Prentice Hall, Upper Saddle River, NJ.

Perlite Institute. 2005. Basic facts about perlite the world's most versatile mineral. Perlite Institute, Harrisburg, PA

Peterson, J.C., L.L. Kramer, and J. O’Bryan. 1989. Just what is in my soil, anyway. Interior Landscape Ind. 6(8):48-50.

Warncke, D. 1988. Recommended test procedures for greenhouse growth media, p. 34-37. In: W.C. Dahnke (ed.). Recommended chemical soil test procedures for the North Central Region. North Dakota Agr. Expt. Sta. Bul. 499. 